\title{
The Effect of Organizational Culture and Empowerment Correlated to Work Engagement as an Intervening Variables Towards to The Service Quality of Employee of General Bureau at The Ministry Of State Secretariat
}

\author{
Koko Haryono \\ State University of Jakarta \\ Email: KokoHaryono_7647130205@mhs.unj.ac.id \\ Henry Eryanto \\ State University of Jakarta \\ Wibowo \\ University Prof. Dr Moestopo
}

\begin{abstract}
The aim of this research is to reveal the effect of organizational culture and empowerment correlated to work engagement as an intervening variable in relations to General Bureau quality serviceability in term of directly nor indirectly, as well as considering the adjusted strategy to enhance serviceability quality. This research uses survey method in quantitative research. The sum of this research is depicted from staff members of General Bureau at The Ministry of State Secretariat of The Republic of Indonesia, with a sample of 76 employees. The technique in analyzing data used SPSS and LISREL. In the result of the research revealed that there is a positive direct effect between organizational culture, empowerment and work engagement on service quality, a positive direct effect on organizational culture and empowerment on work engagement and organizational culture on empowerment, and there is an indirect effect between organizational culture through empowerment, organizational culture and empowerment through work engagement. on service quality. This result will be used as a testimony for the institution in order to maintain as well as elevate and expand the dimension and it's indicator I order to increase service quality of General Bureau 's staffs. Thus, can be concluded that in order to generate an optimal service quality among staffs, an organization necessitates to manufacture and uplift organizational culture, empowerment and work bond among the staffs.
\end{abstract}

Keywords: Organization Culture, Empowerment, Work Engagement and Service Quality.

Received: 9 December 2020 ;

Accepted: 13 January 2021 ;

Publish: June 2021

\section{How to Cite:}

Haryono, K., Eryanto, H., \& Wibowo. (2021). The Effect of Organizational Culture and Empowerment Correlated to Work Engagement as an Intervening Variables Towards to The Service Quality of Employee of General Bureau at The Ministry Of State Secretariat. Journal of Business and Behavioural Entrepreneurship, 5(1), 1-15. https:// doi.org/10.21009/JOBBE.005.1.01 


\section{INTRODUCTION}

The Ministry of State Secretariat has a very strategic role in supporting the fluency of the duties and functions of the President and Vice President in running the government, which is led by the Minister of State Secretary (Ministry of State Secretariat of the Republic of Indonesia, 2015). In carrying out his duties, the Minister of State Secretary is supported by the state civil apparatus that supports administrative and protocol tasks.

Based on the Minister of State Secretary Regulation Number 3, 2015 about the Organization and Work Procedure in the Ministry of State Secretariat, one of the existing Bureaus of the State Secretariat specialized in providing support for household services is the General Bureau. Based on observations and interviews conducted, it is known that there are still several problems in the General Bureau especially in the service quality.

Service quality is very important in creating customer satisfaction, in this case, the leader and all customers, both internal and external of the organization. By giving an optimal service, hopefully, the organization will achieve its targets and goals easier.

Based on previous observations and survey, problems related to the service quality are some of the services are not finish at the expected time, the employees look untidy and impolite when giving the services, lack of coordination between divisions, unequal assignments to the employees, sometimes services are only carried out according to operational working hours.

This information is supported by a preliminary survey that conducted on 30 respondents which found that service quality is the most dominant issue at the General Bureau by $27 \%$, while the rest is affected by other factors. It is also known that there are some service quality indicators that are considered to be less than optimal, such as a display of $57 \%$ and a response to service of $57 \%$ with rarely and never categories.

It is known that there are several factors that are affect the service quality of General Bureau employees of the State Secretariat, such as work motivation, supervision, organizational culture, education and training, empowerment, work engagement, work environment, compensation and employee rotation. Kuldip Singh's research, entitled Influence of Internal Service Quality on Job Performance: A Case Study of the Royal Police Department, suggests that the quality of internal services is positively correlated with job performance. (Kuldip Singh, 2016). This study shows that the quality of internal services has a positive correlation with the police personnel performance.

Dean. A. Koutroumanist, in his research entitled Leadership Paradigms, Generational Differences, And Cultural Norms and Their Effects on Service Quality in The Restaurant Industry, said that developing human resources will increase various aspects of work and employee satisfaction which is positively related to customer satisfaction and loyalty and finally will affect organizational performance. (Koutroumanis \& Dixon, 2018).

The importance of this research is because there has never been any research that examines service quality, especially at the General Bureau of the State Secretariat, which seen from the effect of organizational culture, empowerment and work engagement factors. The previous researches only examined the service quality on customer satisfaction. In addition, the service quality of employee is important to examine, because the services given will affect the performance of the organization's internal customers which will affect organizational performance.

Considering the urgency of the problem in this study, the researcher limits the

The Effect of Organizational Culture and Empowerment Correlated to Work Engagement as an Intervening Variables Towards to The Service Quality of Employee of General Bureau at The Ministry Of State Secretariat. 
research to factors of organizational culture, empowerment, and work engagement which assumed will affect the service quality.

\section{LITERATURE REVIEW}

According to Groetsh and Davis, as stated by Hardiyansyah that "the quality of a service is a dynamic condition that is related to product, service process and its surroundings which fulfills or meets beyond expectations" (Hardiyansyah, 2011). A quality is something that is related to a fulfillment or customers' expectations.

Lewis and Booms as stated by Fandi Tjiptono also stated that a quality service is defined as "how perfect a service level given could result according to customers' expectations" (Tjiptono, 2008). Based on this concept, service quality is determined by the ability of an organization or institution to fulfill customers' needs and aspiration based on their expectation or hope.

In Sampara Lukman's definition stated that the quality of a service is "an act of service given to customers based on service fundamentals that are improved, quick, accurate, hospitable according to service fundamentals standardization as a basic guideline in serving customers" (Lukman, 2004). In this opinion, these indicates varied positive guidelines and prioritizing customers' self-satisfaction with the given service.

In corresponding to Atep Adya Barata's opinion "if an employee is unsatisfied, then you will never gain customer satisfaction" (Barata, 2014). Thus, it is essential to overlook the internal service quality related to the employees' organizational interactions with the accessible facility given on board.

Referring to Zeithamal, Parasuraman and Barry in Graeme Knowls, quality in service is divided into 5 dimensions: 1) Tangibles - the service, physical appearance of the surroundings, equipment, staffs and communication flow, 2) Responsiveness - the ability to help customers at the right time, 3) Reliability - the agility to service in a professional and accurate manner, 4) Assurance - knowledge and staff's hospitality as well as their ability to address their trust and confirmation, 5) Empathy - a personal touch and respect. (Graeme Knowls, 2011)

Referring to the above various concepts on service quality could be synthesized that a service quality is a working activity of a staff correlated to a professional process of handing a service in order to outcome needs and expectations of a customer in the form of real, professional, mindfulness, assurance and empathy. Their indicators are appearance, amenities, frictionless (real act), accuracy, service standardization, staff's ability (act of being professional), agility, service respond (being mindfulness), being punctual, amenity service and prioritizing customers satisfactions, hospitality and indiscriminate (act of empathy).

Whereas Edgar Schein stated that a culture is the form of accumulation which must be distributed and grasped by certain association including their behavior, emotions, and cognitive as well as psychological functions in the stated association. (Schein, 2004)

Joanne Martin in Luthans emphasized the perspective differences in many organizations related to the culture of an organization, that is "when an individual is related with an organization, they are connected to physical appearance, anecdotes, regulation and formal procedures abide by the organization itself, formal behavior code, ritual, tasks, payroll system, language and quirking only understood by inner staff, etc". (Luthans, 2006)

According to Luthans, the culture of an organization has several essential characteristics such as the order or regulation of behavior observation, norms, dominant val-

The Effect of Organizational Culture and Empowerment Correlated to Work Engagement as an Intervening Variables Towards to The Service Quality of Employee of General Bureau at The Ministry Of State Secretariat. 
ue, philosophy, and other benchmarks in the organization (Luthans, et al., 2006). This theory demonstrates behavior conduct which this is a part of a process when a staff is in the middle of interacting each other. According to Robbins, Edi Sutrisno stated there are ten main characteristics that are partially a key role which consists of: 1) member's identity, 2) pressure faction, 3) staffs' objectives, 4) integration unit, 5) control, 6) risk tolerance, 7) appraisal criteria, 8) conflict tolerance, 9) outcome orientation and 10) embracing new system (Sutrisno, et al., 2011).

Corresponding to Edgar Schein, there are three phases in an organizational culture: 1) Artifact are stages seen on the surface (consists of all phenomenon which all man can see and hear, 2) Faith, strategic value, aim, philosophy such as freedom and democracy, 3) Basic Assumption, usually insensible, easily accepted, faith, perception, thoughts and feelings, primary assumption will somehow create organization's selfimage and how it confronts its surroundings (Schein, et al., 2004).

Stand on previous concepts addressed are synthesized that culture in an organization is a system apparatus and the value created are meant to be agreed upon collectively into organizational identity in sustaining stability and environment adaptation based on dimensions such as identity, value system and controlling system. The mentioned dimensions has indicators such as organization vision and mission indicators, symbols, routine celebration (identity), indicator, faith, norms, orientation, appraisal criteria, precedent guidelines, evaluation, stability and communication scheme (controlling system).

Conferring to Sedarmayanti, regarding empowerment in general "it felt more empowering than ever before, either in authority, responsibility or the individual's ability" (Sedarmayanti, et. Al, 2013).

Bawen and Lawler in Gefagnoli defines empowerment as "sharing with front liners' staff to enhance the organization to become better: information on organizational performance, any slight knowledge for staff to understand and make contributions on organizational performance, rewards based on performance and organizational strength to also make a decision which can affect the organizational performance and it's orientation" (Gefagnoli \& Vandekerckhole, 2015).

According to Newstrom et. Al, empowerment is a sovereignty process and decision making are far bigger for staffs in every factor in affecting work outcomes (Riniwati, 2011).

Khan and Sharafat claimed that "in order to empower workers or staffs, we need to make them acknowledge that they have a full support in decision making, to initiate innovation and or creativity, to communicate and sharing goals, to guide by depicting good samples from top managements. A person who has high confidence and wide knowledge are keen to be empowered". (Gefagnoli \& Vandekerckhole, 2015).

According to Kanter, empowerment could be implemented if a person has few supporting conditions such as access to information, support access, source access, formal strength (strengths are distributed based on the organization chart) and informal strength). (Gefagnoli \& Vandekerckhole, 2015).

Based from several expertise on the above empowerment, thus can be synthesized that empowerment is somewhat an effort made by an institution to encourage, handover responsibility and partial authority in the aim to expand abilities and self actualizing of an employee or staff with bearing in mind dimensions of ability, facilitating, teamwork collaboration and guidance. Pointers in empowerment among them are staff guidance, staff training, and opportunities in experiences (capability), information and facilities availability, time management availability, confronting face-toface, communication (consulting), teamwork pointers between leaders and subordi-

The Effect of Organizational Culture and Empowerment Correlated to Work Engagement as an Intervening Variables Towards to The Service Quality of Employee of General Bureau at The Ministry Of State Secretariat. 
nates, co-worker's collaboration (teamwork encouragement), continuous guidance, financial and moralistic endorsement.

On the other hand, Hewitt commented that work connection is "an emotional intellectual statement towards a company or institution which outcomes behavior and supporting in fulfilling customers' needs". Employees who are working in sincerity or just plain voluntary, can also be engaged in a forbidden behavior such as lack of attendance, not punctual and whining (Schierman A, 2011).

Whereas Macy and Scheneider quoted that work bondage consists of employees' characteristics (able to be correlated), even a positive feeling of an employee bonds will arise (Schierman A., et. Al, 2011).

William A. Scheimann defined work bondage consists of three components: (1) a sense of bondage can result a positive vibe in a company or institution and the high level of success aura or euphoria will drive employees to work more or beyond than they can imagine or expect; (2) A sense or work bondage can also predict the behavior of an employee such as wise behavior which results in high empowerment or adaptive behavior such as problem solving and creative decision making can effect productivity, customer loyalty and profit making; (3) Empowerment could effect on a company's actions specially deriving from a supervisor (Schierman A, Et., al, 2011).

According to Schaufeli et. Al defines empowerment as an engagement in positive thinking, satisfactory and related to high vibes and dedication (Schaufeli et al., 2002).

Based on these opinions and theories among expertise, these could be synthesized that work empowerment is a positive behavior which consists of strength, ability and employee self-empowerment (physical, emotional and intellectual) in the result of maximum empowerment, high commitment and active participation towards work and vigor dimension organization, consistent, perseverance, sustainability, enthusiasm, inspiring, content, seeking more challenges, high devotion in work with full concentration as well.

Based on the literature and frameworks, the researcher formulated the hypothesis of the study as follows: 1) organizational culture has a positive direct effect to the service quality of an employee, 2 ) empowering has a positive direct effect to the service quality of an employee, 3 ) work engagement has a positive direct effect to the service quality of an employee, 4) organizational culture has a positive direct effect on work engagement, 5) empowerment has a positive direct effect on work engagement, 6) organizational culture has a positive direct effect on empowerment, 7) organizational culture through empowerment has an indirect effect on service quality, 8) organizational culture through work engagement has an indirect effect on service quality, 9) empowerment through work engagement has an indirect effect on service quality.

\section{RESEARCH METHODS}

This research was conducted at the General Bureau of the State Secretariat Ministry of Republic of Indonesia, from 2017 to 2019. The sample population of this study for the Service Quality variable (Y) were all internal customers of the organization, namely all employees of State Secretariat Ministry other than employee of the General Bureau employees a total of 899 employees. The data analysis unit used as the population for the variables of Organizational Culture (X1), Empowerment (X2) and Work Engagement (X3) were 307 employees of the General Bureau of the State Secretariat Ministry. To determine the sample, the researcher used the Slovin formula technique with random sampling technique. A precision level of $10 \%$ with a confidence level of

The Effect of Organizational Culture and Empowerment Correlated to Work Engagement as an Intervening Variables Towards to The Service Quality of Employee of General Bureau at The Ministry Of State Secretariat. 
$90 \%$, the sample obtained for as many as 76 people.

\section{RESULTS AND DISCUSSIONS}

Description of the research data result includes the descriptions of data related to the respondent's characteristics and descriptions of data related to research variables. The Service Quality variable score was obtained from the average value of 228 respondents by filling out a questionnaire with 35 questions with an average value of 76 . The scoring is done using the Likert model for each question, where the theoretical range of scores on the item is between 35 and 175. Based on the calculation, the results are obtained for the minimum value is 100 , the maximum is 171 , the mean is 133,93 , the frequently occurring value (mode) is 129 , the median value is 113 , the standard deviation is 14,9 and the variance is 222.062 .

The scores for each variable were obtained from 76 respondents. For the respondent's Organizational Culture variable by filling out a questionnaire with 27 questions. The scoring is done using the Likert model for each question, where the theoretical range of scores on the item is between 27 and 135. Based on the calculation, the results are obtained for the minimum value is 84 , the maximum is 135 , the mean is 115,62 , the frequent values (mode) were 109 and 114 , the median was 116 , the standard deviation was 11.29 and the variance was 127.59 .

Meanwhile, the score for the variable of respondents' empowerment filled a questionnaire with 33 questions. The scoring is done using the Likert model for each question, where the theoretical range of scores on the item is between 29 and 165 . Based on the calculation, the results are obtained for the minimum value is 106, the maximum is 165 , the mean is 138,30 , the frequently occurring value (mode) is 143 , the median value is 139.50 , the standard deviation is 15.753 and the variance is 248.161. The score for the work engagement variable was obtained from the respondent by filling in a questionnaire with 23 questions. The scoring is done using the Likert model for each question, where the theoretical range of scores on the item is between 23 and 114. Based on the calculation, the results are obtained for the minimum value is 82 , the maximum is 115 , the mean is 99,92 , the frequently occurring value (mode) is 96 , the median value is 100.50 , the standard deviation is 8.434 and the variance is 71.140

Testing requirements which include normality, linearity and significance tests are carried out before testing the hypothesis. Based on data processing using SPSS 22, the normality test output is shown in Table 1 below.

The Effect of Organizational Culture and Empowerment Correlated to Work Engagement as an Intervening Variables Towards to The Service Quality of Employee of General Bureau at The Ministry Of State Secretariat. 


\section{Table 1}

Normality Data Test Results with

Kolmogorov-Smirnov dan Shapiro Wilk

\begin{tabular}{|c|l|c|c|c|}
\hline No & Model Regresi & $\begin{array}{c}\text { Test Statistc } \\
\text { Kolomogorov } \\
\text { Smirnov }\end{array}$ & Conclusion & Interpretasi \\
\hline 1. & $\mathrm{Y}-\mathrm{X} 1$ & 0,216 & $\mathrm{H}_{0}$ accept & Normal \\
\hline 2. & $\mathrm{Y}-\mathrm{X} 2$ & 0,107 & $\mathrm{H}_{0}$ accept & Normal \\
\hline 3. & $\mathrm{Y}-\mathrm{X} 3$ & 0,117 & $\mathrm{H}_{0}$ accept & Normal \\
\hline 4. & $\mathrm{X} 3-\mathrm{X} 1$ & 0,072 & $\mathrm{H}_{0}$ accept & Normal \\
\hline 5. & $\mathrm{X} 3-\mathrm{X} 2$ & 0,086 & $\mathrm{H}_{0}$ accept & Normal \\
\hline 6. & $\mathrm{X} 2-\mathrm{X} 1$ & 0,104 & $\mathrm{H}_{0}$ accept & Normal \\
\hline
\end{tabular}

From the table above, it shows that the model fulfills the normality assumption by looking at the statistical test score where the sample will be normally distributed if the probability is $>0.05$ then $\mathrm{H} 0$ is accepted, but the population distribution is not normal if the probability then $\mathrm{HO}$ is rejected.

Furthermore, based on the ANOVA results, it is found that the calculation of $f$ count of Suitable Tuna $<$ Ftable $(\alpha=0.05) 3.97$ is shown in the table:

Table 2

\section{Recapitulation of Linearity Test Results}

\begin{tabular}{|c|l|c|c|c|}
\hline No & Model Regresi & F $_{\text {hitung }}$ & F tabel & Result \\
\hline 1. & $\mathrm{Y}-\mathrm{X} 1$ & 0,984 & 3,97 & Linier \\
\hline 2. & $\mathrm{Y}-\mathrm{X} 2$ & 0,589 & 3,97 & Linier \\
\hline 3. & $\mathrm{Y}-\mathrm{X} 3$ & 0,896 & 3,97 & Linier \\
\hline 4. & $\mathrm{X} 3-\mathrm{X} 1$ & 2,154 & 3,97 & Linier \\
\hline 5. & $\mathrm{X} 3-\mathrm{X} 2$ & 0,961 & 3,97 & Linier \\
\hline 6. & $\mathrm{X} 2-\mathrm{X} 1$ & 0,961 & 3,97 & Linier \\
\hline
\end{tabular}

Table 3

Recapitulation of Correlation Coefficient Calculation Results

\begin{tabular}{|c|l|c|c|c|c|}
\hline No & Model Regresi & $\begin{array}{c}\text { Koefisien } \\
\text { Korelasi }\end{array}$ & $\mathbf{t}_{\text {count }}$ & $\mathbf{t}_{\text {table }}$ & Result \\
\hline 1. & Y - X1 & 0,687 & 8,142 & 1,992 & Significant \\
\hline 2. & Y - X2 & 0,680 & 7,967 & 1,992 & Significant \\
\hline 3. & Y - X3 & 0,661 & 7,588 & 1,992 & Significant \\
\hline 4. & X3 - X1 & 0,634 & 7,051 & 1,992 & Significant \\
\hline 5. & X3 - X2 & 0,669 & 7,747 & 1,992 & Significant \\
\hline 6. & X2 - X1 & 0,771 & 8,709 & 1,992 & Significant \\
\hline
\end{tabular}

The Effect of Organizational Culture and Empowerment Correlated to Work Engagement as an Intervening Variables Towards to The Service Quality of Employee of General Bureau at The Ministry Of State Secretariat. 
From the table above, it is known that $\mathrm{t}_{\text {count }}>\mathrm{t}$ table or $\mathrm{H} 0$ is rejected, this means that the correlation between variables is significant.

The structural relationship model is tested for the model fit or Goodness of Fit (GOF) model using the LISREL program package. The test was carried out by involving each indicator that forming the variable in the study, namely Organizational Culture / BO $\left(\mathrm{X}_{1}\right)$ ), Empowerment / PB $\left(\mathrm{X}_{2}\right)$, Work Engagement / KK $\left(\mathrm{X}_{3}\right)$ and Service Quality / KP (Y).

Table 4

Godnes of Fit (GOF) Table

\begin{tabular}{|l|c|l|l|}
\hline \multicolumn{1}{|c|}{ Measurement } & Score & \multicolumn{1}{|c|}{ Description } & \multicolumn{1}{|c|}{ Conclusion } \\
\hline Goodness of Fit Indeks (GFI) & 0,80 & Expected score $>0,80$ & $\begin{array}{l}\text { The model has good com- } \\
\text { patibility }\end{array}$ \\
\hline $\begin{array}{l}\text { Root Mean Square Error of } \\
\text { Approximation (RMSEA) }\end{array}$ & 0,046 & Expected score $<0,08$ & $\begin{array}{l}\text { The model has good com- } \\
\text { patibility }\end{array}$ \\
\hline
\end{tabular}

The table shows the goodness of the models which consist of various sizes. Based on several measures of model goodness, it can be seen that the model proposed in this study is quite good as seen from the RMSEA value which is within the specified limits. In general, the GFI scores show good results. Thus, it can be said that the model is suitable for use.

Based on the results of the statistical test of structural equation models 1,2 and 3 obtained, it can be pictured as follows:

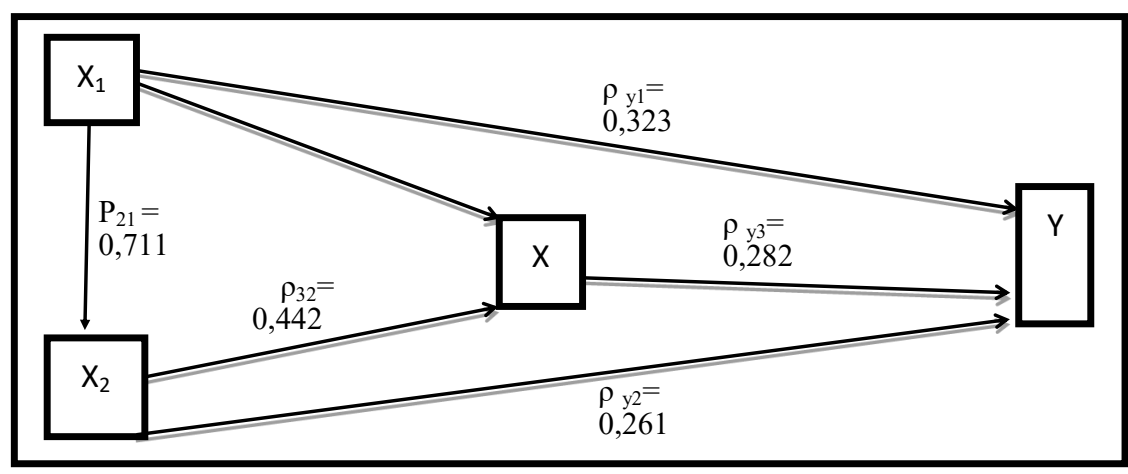

Figure 1. Empirical Model of Structural Relationship Between Variables Based on the Results of Path Analysis

\section{Discussion}

In detail, the discussion of the results of the analysis and testing of the research hypothesis is explained as follows:

\section{Hypothesis Test Results on the Effects of Organizational Culture (X1) towards the Service Quality (Y)}

Based on the results of the hypothesis test, it shows that organizational culture has a direct effect on service quality by 0.323 or $32.3 \%$. The results of further testing carried out by t-test showed that the t-count was 2.852 while the t-table was $1.992(\alpha=$ $0.05)$, because t-count $>$ t-table $(\alpha=0.05)$ and the value of sig. $=0.01<\alpha=0.05$, then $\mathrm{H} 0$ is rejected. The results of testing this hypothesis indicate that there is a positive di-

The Effect of Organizational Culture and Empowerment Correlated to Work Engagement as an Intervening Variables Towards to The Service Quality of Employee of General Bureau at The Ministry Of State Secretariat. 
rect effect of Organizational Culture (X1) on Service Quality (Y). The t-test is carried out to confirm that the positive direct effect of organizational culture on service quality is significant.

From the eleven indicators of organizational culture known that there are two indicators that need to be improved, they are the orientation indicator with a score of 4.13. This shows that employees need more support to achieve goals and targets for improvement in the future.

This indicator needs to be improved because it can contribute to the organization in improving service quality. Meanwhile, other indicators such as vision and mission, symbols, routine celebrations, beliefs, norms, award criteria, rules, evaluation, stability and communication patterns need to be maintained so that these indicators are well preserved.

Based on empirical evidence, the findings of this study indicate that organizational culture is a very important variable and has a positive direct influence on service quality. This means that the increase of organizational culture will lead to an increase in service quality.

\section{Hypothesis Test Results on the Effects of Empowerment (X2) towards the Service Quality (Y)}

This research hypothesis, shows that empowerment has a direct effect on service quality. As big as 0.261 or $26.1 \%$, with a tcount of 2.215 while ttable of $1.992(\alpha=$ $0.05)$, because tcount $>$ ttable $(\alpha=0.05)$ and sig. $=0.00<\alpha=0.05$, then $\mathrm{H} 0$ is rejected. The results of testing this hypothesis indicate that there is a positive direct influence between empowerment (X2) on service quality (Y). The t-test is carried out to confirm that the positive direct effect of empowerment on service quality is significant.

From the fourteen empowerment indicators, it is known that there is one indicator that needs to be improved, which is the face-view indicator with a score of 4.02. This shows that employees need more face-to-face opportunities in carrying out service tasks and achieving organizational goals.

This indicator needs to be improved because it can contribute to the organization in improving service quality. Meanwhile, other indicators like educating, training, the need for experience, information, facilities, time, communication, leadership and subordinates, guidance, morals and finances should be maintained so that these indicators are well preserved.

Based on empirical evidence, the findings of this study indicate that empowerment is a very important variable and has a direct positive effect on service quality. This means that the increase of empowerment will improve the service quality.

\section{Hypothesis Test Results on the Effects of Work Engagement (X3) towards the Service Quality (Y)}

The results of this hypothesis indicate that work engagement has a direct effect on Service Quality by 0.282 or $28.2 \%$, with a tcount of 2.636 , while ttable is $1.992(\alpha$ $=0.05)$, because tcount $>$ ttable $(\alpha=0.05)$. $)$ and the sig. $=0.00<\alpha=0.05$, then $\mathrm{H} 0$ is rejected. The results of this hypothesis test indicate that there is a positive direct effect of Job Engagement (X3) on Service Quality (Y). The t-test is carried out to confirm that the positive direct effect of Job Engagement on Service Quality is significant. 
Based on empirical evidence, the findings of this study indicate that work engagement is a very important variable and has a positive direct effect on service quality. This means that the increase of working engagement will develop the service quality.

\section{Hypothesis Test Results on the Effects of Organizational Culture (X1) on Work Engagement (X3)}

The results of this hypothesis indicate that organizational culture has a direct effect on work engagement by 0.320 or $32 \%$, with a tcount of 2.709 , while ttable is $1.992(\alpha=0.05)$, because tcount $>$ ttable $(\alpha=0.05)$ and $\operatorname{sig}=0.00<\alpha=0.05$, then H0 is rejected which means that Organizational Culture $(\mathrm{X} 1)$ has a positive direct effect on work engagement (X3). The t-test is carried out to confirm that the positive direct effect of Organizational Culture on Work Engagement is significant.

From the eleven indicators of organizational culture noted that there are two indicators that need to be improved, namely the orientation indicator with a score of 4.13. This shows that employees need more support to achieve goals and targets for improvement in the future.

This indicator needs to be improved because it can contribute to the organization in improving service quality. Meanwhile, the other indicators like vision and mission, symbols, routine celebrations, beliefs, norms, award criteria, rules, evaluation, stability and communication patterns need to be maintained so that these indicators are well preserved.

Based on empirical evidence, the findings of this study indicate that organizational culture is a very important variable and has a positive direct effect on work engagement. This means that the increase of organizational culture will lead to an increase in working engagement.

\section{Hypothesis Test Results on the Effect of Empowerment (X2) on Work Engage- ment (X3)}

The test results of this hypothesis show that empowerment has a direct effect on Job Engagement $\neg$ as large as 0.442 or $44.42 \%$, with a tcount of 3.746 , while ttable is $1.992(\alpha=0.05)$, because tcount $>$ ttable $(\alpha=0.05)$. $)$ and $\operatorname{sig}=0.012<\alpha=0.05$, then $\mathrm{H} 0$ is rejected, which means that empowerment (X2) has a positive direct effect on work engagement (X3). The t-test is carried out to confirm that the positive direct effect of empowerment on work engagement is significant.

From the fourteen indicators of empowerment, it is known that there is one indicator that needs to be improved, namely the face-view indicator with 4.02 score. This shows that employees need more face-to-face opportunities in carrying out service tasks and achieving organizational goals.

This indicator needs to be improved because it can contribute to the organization in improving service quality. Meanwhile, other indicators like educating, training, the need for experience, information, facilities, time, communication, leadership and subordinates, guidance, guidance, morals and finances so that they are maintained so that these indicators are well preserved.

The Effect of Organizational Culture and Empowerment Correlated to Work Engagement as an Intervening Variables Towards to The Service Quality of Employee of General Bureau at The Ministry Of State Secretariat. 
Based on empirical evidence, the findings of this study indicate that empowerment is a very important variable and has a positive direct effect on work engagement. This means that the increase of empowerment will lead to an increase in work engagement.

\section{Hypothesis Test Results on the Effect of Organizational Culture (X1) on Empow- erment (X2)}

The test results of this hypothesis indicate that Organizational Culture has a direct effect on empowerment by 0.711 or $71.1 \%$, with a tcount of 8,709 , while ttable is $1.992(\alpha=0.05)$, because tcount $>$ table $(\alpha=0.05)$ and the $\operatorname{sig}=0.012<\alpha=0.05$, then $\mathrm{H} 0$ is rejected, which means that Organizational Culture (X1) has a positive direct effect on empowerment (X2). The t-test is carried out to confirm that the positive direct effect of organizational culture on empowerment is significant.

From the eleven indicators of organizational culture, it is known that there are two indicators that need to be improved, namely the orientation indicator with 4.13 score. This shows that employees need support to achieve goals and targets for improvement in the future.

This indicator needs to be improved because it can contribute to the organization in improving service quality. Meanwhile, the other indicators like vision and mission, symbols, routine celebrations, beliefs, norms, award criteria, rules, evaluation, stability and communication patterns need to be maintained so that these indicators are well preserved.

Based on empirical evidence, the findings of this study indicate that organizational culture is a very important variable and has a positive direct influence on empowerment. This means that the increase of the organizational culture will increase the empowerment.

\section{Hypothesis Test Results on the Effect of Organizational Culture (X1) on Service Quality (Y) through Empowerment (X2)}

In the results of this study using the Sobel Test calculation and obtained a $\mathrm{z}$ value of 2.156. Because the $\mathrm{z}$ score obtained is $2.156>1.96$ (absolute $\mathrm{z}$ value) with a significance level of $5 \%$, it proves that empowerment is able to mediate the influence relationship between organizational culture on the service quality of employees at the General Bureau of the State Secretariat.

Based on the results of the hypothesis test, it shows that organizational culture has a direct effect on service quality by 0.323 or $32.3 \%$.

From the eleven indicators of organizational culture, it is known that there are two indicators that need to be improved, namely the orientation indicator with 4.13 score. This shows that employees need support to achieve goals and targets for improvement in the future.

This indicator needs to be improved because it can contribute to the organization in improving service quality. Meanwhile, vision and mission, symbols, routine celebrations, beliefs, norms, award criteria, rules, evaluation, stability and communication pat-

The Effect of Organizational Culture and Empowerment Correlated to Work Engagement as an Intervening Variables Towards to The Service Quality of Employee of General Bureau at The Ministry Of State Secretariat. 
terns need to be maintained so that these indicators are well preserved.

Related to the reality in the field, the researcher argues that even though the organization has procedures and mechanisms for managing empowerment, as stated by the experts above, including in making policies related to empowerment by considering the needs of employees, there are still gaps as seen in the description of the results data. research. Evidence that the Ministry of State Secretariat has empowerment is by holding education and training which are held regularly every year, and employees are given the opportunity to participate.

Based on empirical evidence, the findings of this study indicate that organizational culture affects service quality through empowerment of employees at the General Bureau, the Ministry of State Secretariat. This means that the increase of organizational culture will improve the service quality through empowerment.

\section{Hypothesis Test Results on the Effect of Organizational Culture (X1) on Service Quality (Y) through Work Engagement (X3)}

In the results of this study using the Sobel Test calculation and obtained a $z$ value of 2.473. Because the $\mathrm{z}$ value obtained is $2.473>1.96$ (absolute $\mathrm{z}$ value) with a significance level of $5 \%$, it proves that work engagement is able to mediate the influence relationship between organizational culture on service quality of employees at the General Bureau of the National Secretariat.

From the eleven indicators of organizational culture, it is known that there are two indicators that need to be improved, namely the orientation indicator with 4.13 score. This shows that employees need support to achieve goals and targets for improvement in the future.

This indicator needs to be improved because it can contribute to the organization in improving service quality. Meanwhile, the other indicators; vision and mission, symbols, routine celebrations, beliefs, norms, award criteria, rules, evaluation, stability and communication patterns need to be maintained so that these indicators are well preserved.

Based on the results of the hypothesis test, it shows that organizational culture has a direct effect on service quality by 0.323 or $32.3 \%$. The results of this study are also supported by Jay Romans and Jeff Tobaben with the title Our Take: Building Cultures Work Engagement, explaining that the key to work engagement is the top team. Effective leaders are constantly looking for new ways forward. They have the principle of rebuilding the path that will motivate and capture the energy from them needed for success which in turn will improve the performance and quality of service for employees (Romans \& Tobaben, 2016).

Based on empirical evidence, the findings of this study indicate that there is an indirect influence between organizational culture on service quality through work engagement with employees at the General Bureau, the Ministry of State Secretariat. This means that the increase of organizational culture will improve the service quality through work engagement.

The Effect of Organizational Culture and Empowerment Correlated to Work Engagement as an Intervening Variables Towards to The Service Quality of Employee of General Bureau at The Ministry Of State Secretariat. 


\section{Hypothesis Test Results of the Effect of Empowerment (X2) on Service Quality (Y) through Work Engagement (X3)}

In the results of this study using the Sobel Test calculation and obtained a $\mathrm{z}$ value of 2.500. Because the $z$ value obtained is 2,500> 1.96 (absolute $z$ value) with a significance level of $5 \%$, it proves that work engagement is able to mediate the influence relationship between organizational culture on the service quality of employees at the General Bureau of State Secretariat

From the fourteen indicators of empowerment, it is known that there is one indicator that needs to be improved, namely the face-view indicator with 4.02 score. This shows that employees need more face-to-face opportunities in carrying out service tasks and achieving organizational goals.

This indicator needs to be improved because it can contribute to the organization in improving service quality. Meanwhile, other indicators; educating, training, the need for experience, information, facilities, time, communication, leadership and subordinates, guidance, guidance, morals and finances so that they are maintained so that these indicators are well preserved.

Related to the reality in the field, the researcher argues that even though the organization has a mechanism to encourage work engagement, as stated by the experts above, including in making policies related to work engagement, there are still gaps as seen in the description of the research data. Evidence that the State Secretariat Ministry has a mechanism to encourage good work engagement, the State Secretariat Ministry has provided employees with opportunities to develop themselves through education and training held, this is one of the empowerment efforts carried out by the organization.

Based on empirical evidence, the findings of this study indicate that there is an indirect influence between empowerment on service quality through work engagement with employees at the General Bureau, the Ministry of State Secretariat. This means that the increase of the empowerment will improve the service quality through employee engagement.

\section{CONCLUSION}

Organizational culture has a direct positive effect on service quality, meaning that if the organizational culture increases, it is predicted that service quality will also increase. Empowerment has a positive direct effect on service quality, means that if empowerment increases, it is predicted that service quality will also increase. Work engagement has a direct positive effect on service quality, means that if work engagement increases, it is predicted that service quality will also increase. Organizational culture has a direct positive effect on work engagement, means that if organizational culture increases, it is predicted that work engagement will also increase. Empowerment has a direct positive effect on work attachments, means that if empowerment increases, it is predicted that work attachments will also increase. Organizational culture has a direct positive effect on empowerment, means that if empowerment increases, it

The Effect of Organizational Culture and Empowerment Correlated to Work Engagement as an Intervening Variables Towards to The Service Quality of Employee of General Bureau at The Ministry Of State Secretariat. 
is predicted that work attachments will also increase. Organizational culture has a direct positive effect on empowerment, means that if empowerment increases, it is predicted that work attachments will also increase. Service quality has an indirect effect on organizational culture through empowerment, empowerment, means empowerment is able to mediate the influence of organizational culture on service quality. Service quality has an indirect effect on organizational culture through work engagement, meaning that work engagement is able to mediate the influence of organizational culture on service quality. Service quality has an indirect effect on empowerment through work engagement, meaning that work engagement is able to mediate the influence of organizational culture on service quality.

\section{REFERENCES}

Abdhy, A. A. (2016). Effect of empowerment and psychological contract on university employee keterikatan kerja. International Journal of Economics, Commerce and Management, $\operatorname{IV}(8), 1-13$.

Ajudia, A. (2016). Pengaruh Pemberdayaan Pegawai terhadap Kualitas Pelayanan Publik di Kantor Pelayanan Wilayah Utama Perusahaan Daerah Air Minum (PDAM) Tirta Khatulistiwa Pontianak,. Studi, Program Pemerintahan, Ilmu Fakultas, Kerjasama Sosial, Ilmu Universitas, Politik, 1-11.

Al-dmour, H. (2019). The Impact of Employee Empowerment upon Sales Workforce Performance via the Mediating Role of Work Keterikatan kerja in the Five Stars Hotels : Empirical Study. 2(2), 1-21.

Anantan, L. (2008). Service Exellence; Competing Through Competitivenes. Bandung: Alfabeta.

Barata, A. A. (2014). Dasar-dasar Pelayanan Prima; Persiapan Membangun Budaya Pelayanan Prima untuk Meningkatkan Kepuasan dan Loyalitas Pelanggan. Jakarta: Gramedia.

Finneley, M. I. (2011). Keterikatan kerja. Jakarta: PPM.

Gefagnoli, J., \& Vandekerckhole, T. (2015). Distributed Leadership; Potential \& Implementation through self-managed teams. Sweden: Linnaeus University.

Graeme Knowls. (2011). Quality Management. London; Bookboon.com.

Hardiyansyah. (2011). Kualitas Pelayanan Publik: Konsep, Dimensi, Indikator dan Implementasinya. Yogyakarta: Gava Media.

Kementerian Pendayagunaan Aparatur Negara dan Reformasi Birokrasi. (2012). Permenpan RB No 39 Tahun 2012 tentang Pedoman Pengembangan Budaya Kerja.

Kementerian Sekretariat Negara RI. (2015). Permensesneg Nomor 3 tahun 2015 tentang Organisasi dan Tata Kerja Kemensetneg RI. Jakarta: Kemensetneg RI.

Kompaso, S. M., \& Sridevi, M. S. (2010). Employee Keterikatan kerja: The Key to Improving Performance. International Journal of Business and Management, 5 (12), 89-96. https://doi.org/10.5539/ijbm.v5n12p89

Kreitner, R., \& Angelo Kinichi. (2012). Perilaku Organisasi. Jakarta: Salemba Empat.

Lukman, S. (2004). Manajemen Kualitas Pelayanan. Jakarta: Sekolah Tinggi Ilmu Administrasi Lembaga Administrasi Negara.

Luthans, F. (2006). Perilaku Organisasi. Yogyakarta: Andi.

Makmur, S. (2008). Pemberdayaan Sumber Daya Manusia dan Efektivitas Organisasi. Jakarta: Rajagrafindo Persada.

Osborne, S., \& Hammoud, M. S. (2017). Effective Employee Keterikatan kerja in the

The Effect of Organizational Culture and Empowerment Correlated to Work Engagement as an Intervening Variables Towards to The Service Quality of Employee of General Bureau at The Ministry Of State Secretariat. 
Workplace. International Journal of Applied Management and Technology, 16(1), 50-67. https://doi.org/10.5590/IJAMT.2017.16.1.04

Priansa Suwatno, \& Juni, D. (2012). Manajemen SDM dalam Organisasi Publik dan Bisnis. Bandung: Alfabeta.

Riniwati, H. (2011). Mendongkrak Motivasi dan Kinerja. Malang: Universitas Brawijaya.

Romans, J., \& Tobaben, J. (2016). Our take: building keterikatan kerja cultures. Strategic HR Review, 15(2), 76-82. https://doi.org/10.1108/shr-02-2016-0010

Schaufeli, W. B., Salanova, M., Gonz, V., Rom, A., \& Bakker, A. B. (2002). The Measurement of Keterikatan kerja and Burnout: A Two Sample Confirmatory Factor Analytic Approach. Netherland: Kluwer Academic Publisher.

Schein, E. H. (2004). Organizational Culture and Leadership (3rd ed.). San Francisco: Jossey Bass.

Schierman A, W. (2011). Alignment Capability Keterikatan kerja; Pendekatan Baru Talent Mangement untuk Mendongkrak Kinerja Organisasi. Jakarta: PPM UGM.

Sedarmayanti. (2013). Manajemen Sumber Daya Manusia; Reformasi Birokrasi dan Manajemen Sumber Daya Manusia (B. R. Aditama (ed.)).

Shakibaei, Z., Khalkhali, A., \& Nezgad, S. S. (2012). Relationship Between Organizational Culture Type and Empowering Staff in Manufacturing Companies of Iran. Procedia - Social and Behavioral Sciences, 46, 2886-2889. https:// doi.org/10.1016/j.sbspro.2012.05.583

Sumaryadi, I. N. (2010). Sosiologi Pemerintahan; Dari Perspektif Pelayanan, Pemberdayaan,Interaksi dan Sistem Kepemimpinan Permerintah Indonesia. Bogor: Ghalia.

Sutrisno, E. (2011). Budaya Organisasi (II). Jakarta: Kencana Prenada Media Group.

Tjiptono, F. (2008). Service Management: Mewujudkan Pelayanan Prima (2nd ed.). Yogyakarta: Fandi Tjiptono.

Tsoukatos, E. (2007). Impact of culture on service qualityn What we know and what we need to learn. Table 1.

Wibowo. (2013). Budaya Organisasi; Sebuah Kebutuhan untuk Meningkatkan Kinerja Jangka Panjang. Jakarta: Rajagrafindo Persada.

Yustina, A. I. (2017). Effects of Ethical Leadership on Employee Well-Being : 32(2), $121-137$

The Effect of Organizational Culture and Empowerment Correlated to Work Engagement as an Intervening Variables Towards to The Service Quality of Employee of General Bureau at The Ministry Of State Secretariat. 